\title{
Effect of weed control technologies on chickpeas (Cicer arietinum L.) and weeds
}

\author{
I. Kristó ${ }^{1}{ }^{*}$, M. Tar ${ }^{1}$, V. J. Vojnich ${ }^{2}$, M. V. Nagy ${ }^{1}$ \\ ${ }^{1}$ National Agricultural Research and Innovation Centre, Department of Field Crops Research, Lower Harbor Row 9 , \\ H-6726 Szeged, Hungary \\ 2University of Szeged Faculty of Agriculture, Andrássy Street 15, H-6800, Hódmezővásárhely, Hungary, \\ *e-mail: kristo.istvan@noko.naik.hu
}

Purpose. In our experiment, effect of weed technologies on chickpeas (Cicer arietium L.) was set up in 2018 and 2019 at the Szeged-Öthalom experimental area. Methods. In the first year we applied mechanical weed control in addition to pre-emergence herbicide (May 19, 2018) and 6-8 leaf chickpeas (June 20, 2018) in addition to post-emergence herbicide treatments. The year 2019 was different in that after the preemergence treatment (April 10, 2019), the post-emergence treatment of chickpeas with 6-8 leaf condition (May 15, 2019) was repeated in the budding state (June 18, 2019). The yield components one way analysis of variance was prepared using SPSS 22 software and graphic representation of the development of the plants was carried out Svab's cumulative yield analysis. Results. The effect of the treatments of 2018 and 2019 on the yield elements of chickpeas can be illustrated graphically in Figure 1 and Figure 2. For both years, the data are from plots of the 'Reale' variety, where the $100 \%$ level is made up of the yield elements of the weed-free plots, and the yield elements of the other treatments are compared to this. Figure 1 shows that the number of shoots per unit area $\left(1 \mathrm{~m}^{2}\right)$ of weed-free plots that did not control weeds was $15 \%$, the number of pods $45 \%$, the number of seeds $58 \%$ and the weight of seeds $49 \%$ less than the weed-free control plots the same crop elements. Weeds were also significantly present in the plots treated only with pre-emergence treatment in the second half of the growing season, so the number of shoots per unit area was $3 \%$, the number of pods $23 \%$, the number of seeds $34 \%$ and the seed weight $35 \%$ lower, as on weed-free plots. In the case of herbicide treatments, the decrease in yield elements was much smaller: the number of plants per unit area by $1 \%$, the number of shoots by $3-10 \%$, the number of pods by $5-12 \%$, the number of seeds by $13-18 \%$, the seed weight was by $1-5 \%$ less than on mechanically weed-controlled plots. Conclusions. Our two-year weed survey results show that the later sowing time of chickpeas favored warm-loving weeds. This is in complete agreement with the opinion of Nagy (2017), who found that sowing time determines the predominant weed species in a given area. At the same time, the statement of Kurnik (1970) was not confirmed, since in our experiment we proved in the case of 'Reale' cultivar that the later sowing stock in 2018 gave higher yields than the plots with earlier sowing time in 2019. The changing weather caused by climate change makes the site characteristics of the given period much more unpredictable, so the yield is determined much more by the field factors developed during the growing season than by the calendar period.

Ключові слова: Chickpeas; variety; yield; nutrient level; seeding rate.

\section{Introduction}

Chickpeas are one of the oldest known and cultivated plants in Hungary [1]. Southeast Asia is considered to be its homeland (ancestral home), dating back to 3000-4000 BC. According to the findings, it was also cultivated and consumed by the ancient Hungarians. Until the 18th century, it was common in Hungarian gastronomy: its flour was baked into noodles and its seeds roasted as coffee substitutes. It was later forgotten about its cultivation and consumption, too [2]. Nowadays, with the spread of the reform diet, it is becoming popular again. In 2018, only 272 ha were cultivated in Hungary, but statistics show that market demand and cultivation will continue to grow [3]. A valuable feature is the extreme drought

Kristó, I., Tar, M., Vojnich, V. J., \& Nagy, M. V. (2019). Effect of weed control technologies on chickpeas (Cicer arietinum L.) and weeds. Novitnì agrotehnologiï [Advanced agritechnologies], 7. Retrieved from http://jna.bio.gov.ua/article/view/204790. 
tolerance and collection of nitrogen using Mesorhizobium bacteria [4]. It can be successfully grown under harsh conditions without irrigation, which is of increasing importance with climate change $[5,6]$.

In traditional cultivation, the weed control of chickpeas is mainly mechanical. Due to the increased labor shortage, chemical weed control has come to the forefront mainly for economic reasons [7], and other alternative weed control methods are being explored. In order to prevent the possible emergence of herbicide resistance through the use of pesticides and the replacement of synthetic herbicides, more and more alternatives have been adopted. Waqas et al. (2016) in Saudi Arabia, he used mulch as a weed control tool (black, white plastic foil, sawdust, wheat straw) and compared their effect with preemergence herbicides [8]. Did the same Khan et al. (2011, 2017, and 2018) in Pakistan, combined with mugwort and eucalyptus herb extracts to exploit the allelopathy effect. Their results show that, while covering mulch techniques with black plastic foil has yielded promising yield results, overall it currently offers a more expensive solution than herbicide choices. Among the plant essences, the efficacy of eucalyptus treatment was outstanding [9-11].

Chickpeas have a low weed-suppressing capacity during the early stages of development. Providing the conditions necessary for good germination, rapid, uniform emergence and growth with each of the agrotechnical elements can reduce the habitat of weeds [12]. Chickpeas are the largest crop after wheat, so they are usually sown between two cereals. After self-cultivation is not recommended. Other forecrops can be poppy, canola, linseed, hemp. Sunflower should be avoided due to self-sown, and sorghum should be a potential herbicide residue and late harvest [1]. Consideration should be given to the herbicide used in the cultivation of the forecrop. Herbicides containing mesotrione, isoxaflutole or aminopyralid cannot be sown as a leguminous plant, as phytotoxic symptoms may occur in emergent cotyledonous culture [13]. Soil cultivation is an important element of agrotechnical weed control [14]. Plowing and stubble cultivation can greatly reduce the seedling weeds and root weeds in the area. However, with the spread of shallow cultivation, an increased spread of Cirsium arvense or Convulvulus arvensis is expected [13]. The sowing time is determined by the soil temperature, which in Hungary is from the beginning of March to the beginning of April. By extending sowing time, weed control work can be reduced, but at the same time, chick peas sown from mid-April lead to a decline in yield [15].

At the beginning of the development of chickpeas, it has a weak weed-suppressing ability, its two critical periods can be attributed to 20-25 days after emergence and the entire flowering period [16]. The rare, not well-closing stock can later become weeded, in which case the yield can fall by as much as half. The resulting yield loss can be as high as 40-87\% [7]. In addition, Waqas et al. (2016) show that weed infestation has a significant effect on the growth and yield of chickpeas, and yield surplus can only be successful by coordinating weeds [8]. The Hungarian practice mentions the use of herbicides applied to the seedbed $[1,17]$. Following drug withdrawals, the range of active substances that can be used has now been significantly narrowed: s-metolachlor is currently the only authorized preemergent herbicide. The use of a preemergent herbicide alone may not be satisfactory in all cases, as Muhhamad et al. (2011) supports found that the use of preemergent herbicides increased yields by $12-14 \%$ and postemergent herbicides by $6-23 \%$ [18]. The main advantage of post-emergence (post) agents is that they act specifically against the weeds present, at an appropriate phenological stage [14]. However, their use in chickpeas can only be done with occasional permission. Therefore, Plew et al. (1994) and Khope et al. (2011) used fodder peas and soy herbicides in chickpeas at the dose specified in the license [7, 19]. Nádasdyné (2015) studied the effect of double dose in feed peas using Afalon Dispersion, Sencor and Stomp, at which time phytotoxic symptoms appeared and the tendency of peas to germinate and grow decreased. In the case of linuron and metribuzin herbicides, the humus content was also an exclusion factor: below $1.5 \%$, the product easily washed into the root zone of peas. When clomazone was applied, transient yellowing, whitening spots appeared on the leaf [20]. Transient phytotoxic symptoms appeared in Goud et al. (2013) in chickpea experiments: on day 35 after imazetapir and quizalofop-P-ethyl treatments, minimal damage became visible that the plant grew over time [21]. Taran et al. (2013) experienced more severe symptoms: decreased yield, leaf necrosis, eye injury with metribuzin herbicide; and imazetapir and imazamox produced dwarfism and chlorosis [22]. However, they found that the extent of injury was greatly influenced by environmental factors and variety choice. The same was experienced by Khan et al. (2011) treatment with imazetapyr, where plants were bushy, and leaves remained dwarfs. This developmental disorder later manifested itself in crop formation [9].

Comparing the available agents, both preemergence and postemergence can be applied in their herbicide experiments Ratnam et al. (2011), Waqas et al. (2016), and Merga et al. (2019) found a maxiumum herbicidal effect at Stomp, emphasizing that it does not cause visible damage to plants [5, 8, 
23]. At the same time, Soudhia (2012) draws attention to the residues found in herbicides with pendimethalin, which, according to his observations, can be detected in low-dose residues in soil, crops, grain yields, and chickpea straw [24].

\section{Material and method}

Our experiment was set up in 2018 and 2019 at the Szeged-Öthalom experimental site of the Plant Production Independent Research Department of the National Agricultural Research and Innovation Center. Soil characteristics of the experiment: meadow chernozem soil, humus content 2.8-3.2\%, pH 7.9. Based on the Arany-type plasticity index (KA $=42)$; a medium nitrogen content $(24.0 \mathrm{mg} / \mathrm{kg})$, a good phosphorus content $(248 \mathrm{mg} / \mathrm{kg})$ and a potassium content $(209 \mathrm{mg} / \mathrm{kg})$.

The forecrop of the experimental plots was winter wheat in both years. Organic fertilizer application has not been possible for the last 5 years, as a basic fertilizer (Nitrogen, Phosphorus, Potassium) we applied $200 \mathrm{~kg}$ of complex fertilizer (active substance: Nitrogen 8\%; Phosphorus 24\%, Potassium 24\%, and Sulphur 3\%) in the autumn. Sowing dates were May 12, 2018 and April 9, 2019. In 2018, 'Reale' variety, in 2019 'Reale' and 'Bori' varieties were planted with $36 \mathrm{~cm}$ row spacing, $5 \mathrm{~cm}$ seeding depth, 500,000 thousand germ/ha germination in 4 replications, $10 \mathrm{~m}^{2}$ area, plots a random block design. The treatments of the plots are shown in Table 1. In the first year we applied mechanical weed control in addition to pre-emergence herbicide (May 19, 2018) and 6-8 leaf chickpeas (June 20,2018) in addition to post-emergence herbicide treatments. The year 2019 was different in that after the pre-emergence treatment (April 10, 2019), the post-emergence treatment of chickpeas with 6-8 leaf condition (May 15, 2019) was repeated in the budding state (June 18, 2019).

Table 1

Treatments used in the experiment

\begin{tabular}{|c|c|c|c|c|c|}
\hline $\begin{array}{l}\text { Treat- } \\
\text { ments }\end{array}$ & Pesticides & Active substance & $\begin{array}{l}\text { Dose } \\
\text { (l/ha) }\end{array}$ & $\begin{array}{c}\text { Phenological status } \\
\text { of chickpeas in } 2018 \\
\text { treatments }\end{array}$ & $\begin{array}{c}\text { Phenological status of } \\
\text { chickpeas in } 2019 \\
\text { treatments }\end{array}$ \\
\hline 1 & $\begin{array}{l}\text { Weed-free } \\
\text { control }\end{array}$ & - & - & - & - \\
\hline 2 & Weed control & - & - & - & - \\
\hline 3 & Stomp Super & pendimetalin & 4.5 & preemergence & preemergence \\
\hline 4 & $\begin{array}{l}\text { Basagran } \\
480 \text { SL } \\
\end{array}$ & bentazon & 2 & 6-8 leaf & $\begin{array}{l}6-8 \text { leaf, } \\
\text { budding state }\end{array}$ \\
\hline 5 & $\begin{array}{l}\text { Stomp Super } \\
+ \\
\text { Basagran } \\
480 \mathrm{SL} \\
\end{array}$ & $\begin{array}{l}\text { pendimetalin } \\
+ \\
\text { bentazon }\end{array}$ & $\begin{array}{l}4.5 \\
+ \\
2\end{array}$ & $\begin{array}{l}\text { preemergence, } \\
6-8 \text { leaf }\end{array}$ & $\begin{array}{l}\text { preemergence, } \\
6-8 \text { leaf, } \\
\text { budding state }\end{array}$ \\
\hline 6 & Corum & $\begin{array}{l}\text { imazamox and } \\
\text { bentazon }\end{array}$ & 1.25 & 6-8 leaf & $\begin{array}{l}6-8 \text { leaf, } \\
\text { budding state }\end{array}$ \\
\hline 7 & Pulsar 40 SL & imazamox & 1 & 6-8 leaf & $\begin{array}{l}6-8 \text { leaf, } \\
\text { budding state }\end{array}$ \\
\hline 8 & $\begin{array}{l}\text { Corum } \\
+ \\
\text { Dash HC }\end{array}$ & $\begin{array}{l}\text { imazamox and } \\
\text { bentazon }+ \\
\text { metiolelát and } \\
\text { metilpalmitát }\end{array}$ & $\begin{array}{l}1.25 \\
+ \\
0.5\end{array}$ & 6-8 leaf & $\begin{array}{l}6-8 \text { leaf, } \\
\text { budding state }\end{array}$ \\
\hline
\end{tabular}

Precipitation data for the experimental years are shown in Table 2. Both the winter period of 2018 and 2019 were poor in precipitation, so spring precipitation first had to make up for the lack of moisture in the soil. In 2019, soil temperature allowed us to sow a month earlier than a year earlier.

Weed surveys were performed on the day of herbicide treatments and one week thereafter, as well as before harvest. Thus, in 2018, weed surveys were conducted on 19 May, 25 May, 20 June, 27 June, and 10 September. In 2019, we carried out weed surveys using the Balázs-Ujváros method on 10 April, 17 April, 15 May, 22 June, 18 June and 13 August.

In order to exactly assess the effect of the applied weed control technologies on the development of the plants, plant samples were taken from the $1 \mathrm{~m}^{2}$ part of the plots before harvest and processed by crop analysis. During processing in the number of plants per unit area, the number of plant sprouts, the number of legumes, the number of seeds, and the weight of the seeds were determined. The yield components one way analysis of variance was prepared using SPSS 22 software and graphic 
representation of the development of the plants was carried out Svab's cumulative yield analysis [25-27]. In the Svab's cumulative yield analysis, we refer to the value of each yield-determining component per unit area, and their order follows the development periods of the plant. The yield components are the end products of each developmental stage of the plant, which well characterize the environmental effects in the given and previous developmental stages. Due to the irreplaceability of yield components, the cumulative yield analysis allows us to see a development process through the cumulative yield analysis, from which it can be deduced the direction and extent of the effect of the agrotechnical or ecological element, from which the yield is ultimately formed.

Table 2

Rainfall (mm) for the two growing seasons examined

\begin{tabular}{lcc}
\hline \multicolumn{1}{c}{ Month } & Year 2018 & Year 2019 \\
\hline March & 82.6 & 2 \\
April & 33.1 & 55.5 \\
May & 31.3 & 136.5 \\
June & 166.7 & 134.7 \\
July & 36 & 26 \\
August & 37.2 & 30 \\
September & 7.5 & 40 \\
\hline
\end{tabular}

\section{Results and discussions}

Table 3 illustrates the weed conditions of the weed control plots at the time of the 2018 surveys. It can be seen from the table that of the 19 weed species in the area, there was only one that germinated in cooler weather (Sinapis arvensis), the other warm-loving plants, mostly seedlings, were dicotyledonous plant. For the first two weed surveys, hardly any weeds appeared in the area. For the third survey, summer, warm-loving weeds appeared due to heavy rainfall in the summer, reaching a total coverage of $34.4 \%$. The weed cover of the area continued to increase, so we were able to register almost $80 \%$ weed cover for the harvest in early September. Overall, the highest proportions are Hibiscus trionum, Portulaca oleracea, Solanum nigrum, Chenopodium album, Chenopodium hybridum and Convolvulus arvensis produced with the highest proportion in the experimental area.

Table 3

Weed cover of weed control plots in 2018

\begin{tabular}{llccccc}
\hline \multirow{2}{*}{ Weed } & BAYER & \multicolumn{5}{c}{ Weed cover, \% } \\
\cline { 3 - 7 } & code & 19 May & 25 May & 20 June & 27 June & 10 Sept. \\
\hline Sinapis arvensis & SINAR & 0 & 0.1 & 0.3 & 0.3 & 0 \\
Fumaria schlecheri & FUMSC & 0 & 0.1 & 0.5 & 0.5 & 0 \\
Heliotropium europaeum & HEOEU & 0 & 0.2 & 1 & 1.1 & 0 \\
Hibiscus trionum & HIBTR & 0 & 0.1 & 3 & 3.2 & 2.5 \\
Amaranthus blitoides & AMABL & 0 & 0.1 & 1.5 & 1.6 & 2 \\
Portulaca oleracea & POROL & 0 & 0 & 2 & 2.5 & 5 \\
Echinocloa crus-galli & ECHCG & 0 & 0 & 2 & 2 & 1 \\
Solanum nigrum & SOLNI & 0 & 0.2 & 2 & 2.5 & 23 \\
Chenopodium album & CHEAL & 0 & 0.2 & 3 & 3 & 8 \\
Ambrosia artemisiifolia & AMBEL & 0 & 0.1 & 1.5 & 1.7 & 3 \\
Polygonum persicaria & POLPE & 0 & 0 & 1 & 1 & 2 \\
Galinsoga parviflora & GASPA & 0 & 0 & 1 & 1 & 0 \\
Chenopodium hybridum & CHEHY & 0 & 0.1 & 4.2 & 4.5 & 5 \\
Stachys annua & STAAN & 0 & 0 & 0.5 & 0.5 & 0 \\
Anagallis arvensis & ANGAR & 0 & 0 & 1.8 & 2 & 0.5 \\
Xanthium strumarium & XANST & 0 & 0 & 1.1 & 1.2 & 2 \\
Polygonum convolvulus & POLCO & 0 & 0 & 2 & 2 & 1 \\
Cirsium arvense & CIRAR & 0 & 0 & 1 & 1.1 & 5 \\
Convolvulus arvensis & TONAR & 0 & 0 & 5 & 5.3 & 18 \\
\hline \multicolumn{2}{c}{$\quad 0$} & $\mathbf{0}$ & $\mathbf{1 . 2}$ & $\mathbf{3 4 . 4}$ & $\mathbf{3 7}$ & $\mathbf{7 8}$ \\
\hline
\end{tabular}


In 2019, due to the early sowing time, weeds that favor cooler weather (Sinapis arvensis, Consolida orientalis) were present in a higher proportion in the experimental area (Table 4) than in the previous year. However, because of the dry spring it had no significant weed the plots at the beginning of the growing season. The summer rains caused a large amount of weeding, and by the 5 th weed survey, $85.4 \%$ of the experimental area was covered by weeds. The weed cover of the area only increased in the future, so we experienced $89.3 \%$ weed cover for the harvest in mid-August. We observed that in 2019, after a pre-emergent and post-emergent herbicide plants 6-8 leaf stage of the weeds emerged in masse under late, heavy rainfall, causing a kind of secondary weeding. Overall, the highest proportion of Sinapis arvensis, Portulaca oleracea, Echinochloa crus-galli, Solanum nigrum, Fallopia convolvulus and Convolvulus arvensis occurred.

Weed cover of weed control plots in 2019

Table 4

\begin{tabular}{|c|c|c|c|c|c|c|c|c|}
\hline \multirow[b]{2}{*}{ Weed } & \multirow{2}{*}{$\begin{array}{l}\text { BAYER } \\
\text { code }\end{array}$} & \multicolumn{7}{|c|}{ Weed cover \% } \\
\hline & & 10 April & 17 April & 15 May & 22 May & 18 June & 25 June & $\begin{array}{c}13 \\
\text { August }\end{array}$ \\
\hline Consolida orientalis & CNSOR & 0 & 1.3 & 3.0 & 4.0 & 2.0 & 0 & 0 \\
\hline Sinapis arvensis & SINAR & 0 & 1.0 & 1.5 & 3.4 & 4.0 & 3.1 & 0 \\
\hline Fumaria schlecheri & FUMSC & 0 & 1.3 & 1.5 & 1.0 & 0.5 & 0 & 0 \\
\hline Heliotropium europaeum & HEOEU & 0 & 0.1 & 1.0 & 2.0 & 1.5 & 1.0 & 0.5 \\
\hline Hibiscus trionum & HIBTR & 0 & 0.1 & 0.5 & 0.8 & 1.0 & 1.0 & 0.5 \\
\hline Amaranthus blitoides & AMABL & 0 & 0 & 0.5 & 1.0 & 1.3 & 1.5 & 1.9 \\
\hline Portulaca oleracea & POROL & 0 & 0 & 0.5 & 3.0 & 20.0 & 23.8 & 35.0 \\
\hline Echinocloa crus-galli & ECHCG & 0 & 0 & 1.0 & 1.5 & 6.0 & 6.3 & 2.0 \\
\hline Solanum nigrum & SOLNI & 0 & 0 & 0.5 & 1.0 & 5.4 & 6.5 & 13.0 \\
\hline Chenopodium album & CHEAL & 0 & 0 & 0.5 & 1.0 & 1.4 & 1.6 & 1.0 \\
\hline Ambrosia artemisiifolia & AMBEL & 0 & 0 & 0.3 & 0.5 & 1.3 & 1.4 & 3.0 \\
\hline Polygonum persicaria & POLPE & 0 & 0 & 0.2 & 0.2 & 0.6 & 0.8 & 1.8 \\
\hline Galinsoga parviflora & GASPA & 0 & 0 & 0 & 0.5 & 0.6 & 1.0 & 0 \\
\hline Chenopodium hybridum & CHEHY & 0 & 0 & 0.5 & 1.0 & 2.0 & 2.1 & 3.3 \\
\hline Stachys annua & STAAN & 0 & 0 & 1.0 & 1.1 & 1.5 & 1.5 & 0.5 \\
\hline Anagallis arvensis & ANGAR & 0 & 0 & 0.8 & 1.0 & 1.0 & 0.5 & 0 \\
\hline Xanthium strumarium & XANST & 0 & 0 & 0.5 & 0.5 & 1.0 & 1.0 & 1.0 \\
\hline Polygonum convolvulus & POLCO & 0 & 0 & 5.0 & 7.0 & 21.0 & 20.0 & 0 \\
\hline Helianthus annuus & HELAN & 0 & 0 & 0.5 & 0.6 & 1.0 & 1.3 & 1.5 \\
\hline Cirsium arvense & CIRAR & 0 & 0 & 0 & 0.3 & 1.0 & 1.0 & 1.8 \\
\hline Convolvulus arvensis & CONAR & 0 & 0 & 1.0 & 5.6 & 11.3 & 13.5 & 22.5 \\
\hline
\end{tabular}

The effect of the studied herbicides on the 6 most significant weeds in 2018 is illustrated in Table 5. It can be seen that the pre-emergent applied Stomp Super was almost ineffective on Portulaca oleracea and Convolvulus arvensis, had poor efficacy on Hibiscus trionum and Solanum nigrum, and achieved moderately efficacy on the Chenopodium album. Basagran 480 SL had a weak herbicidal against Hibiscus trionum, Portulaca oleracea and Convolvulus arvensis weeds, and was very effective against Solanum nigrum, Chenopodium album and Chenopodium hybridum.

Pulsar 40 SL was ineffective against Convolvulus arvensis and had a weak herbicidal against Hibiscus trionum. It has a moderately herbicide activity against Chenopodium album and Chenopodium hybridum, a good herbicidal against Solanum nigrum, and excellent efficacy against Portulaca oleracea. Corum had a weak herbicidal against Convolvulus arvensis, and achieved moderately efficacy on the Hibiscus trionum. Corum has good herbicides against Solanum nigrum and Chenopodium hybridum and excellent herbicides against Portulaca oleracea and Convolvulus arvensis. In our experiment, Dash HC adjuvant did not significantly affect herbicidal efficacy. 
Weed control efficiency of the 6 most significant weeds in 2018

\begin{tabular}{|c|c|c|c|c|c|c|c|}
\hline \multirow{2}{*}{ Treatments } & \multirow{2}{*}{ Date } & \multicolumn{6}{|c|}{ Weed control efficiency (\%) } \\
\hline & & HIBTR & POROL & SOLNI & CHEAL & CHEHY & CONAR \\
\hline \multirow{4}{*}{$\begin{array}{l}\mathbf{3} \text { (Stomp } \\
\text { Super) }\end{array}$} & 25 May & 54 & - & 65 & 85 & 80 & - \\
\hline & 20 June & 60 & 10 & 57 & 82 & 74 & 20 \\
\hline & 27 June & 60 & 10 & 50 & 81 & 73 & 20 \\
\hline & 10 September & 60 & 10 & 50 & 75 & 74 & 10 \\
\hline \multirow{2}{*}{$\begin{array}{l}4 \text { (Basagran } \\
480 \mathrm{SL})\end{array}$} & 27 June & 74 & 42 & 98 & 99 & 98 & 49 \\
\hline & 10 September & 66 & 55 & 81 & 91 & 89 & 38 \\
\hline \multirow{4}{*}{$\begin{array}{l}\mathbf{5} \text { (Stomp } \\
\text { Super }+ \\
\text { Basagran } 480 \\
\text { SL) }\end{array}$} & 25 May & 54 & - & 61 & 86 & 80 & - \\
\hline & 20 June & 60 & 10 & 59 & 82 & 83 & 15 \\
\hline & 27 June & 72 & 43 & 100 & 98 & 97 & 47 \\
\hline & 10 September & 68 & 51 & 83 & 89 & 87 & 35 \\
\hline \multirow{2}{*}{6 (Corum) } & 27 June & 85 & 100 & 95 & 100 & 95 & 60 \\
\hline & 10 September & 80 & 100 & 76 & 100 & 90 & 65 \\
\hline \multirow{2}{*}{$\begin{array}{l}7 \text { (Pulsar } \\
40 \mathrm{SL} \text { ) }\end{array}$} & 27 June & 62 & 100 & 95 & 82 & 80 & 10 \\
\hline & 10 September & 64 & 100 & 75 & 78 & 76 & 10 \\
\hline \multirow{2}{*}{$\begin{array}{l}\text { (Corum } \\
+ \text { Dash HC) }\end{array}$} & 27 June & 89 & 100 & 96 & 100 & 96 & 65 \\
\hline & 10 September & 81 & 100 & 76 & 100 & 92 & 70 \\
\hline
\end{tabular}

The effect of the studied herbicides on the 6 most significant weeds in 2019 is illustrated in Table 6. It was observed that the herbicidal effect of Stomp Super was almost ineffective against Fallopia convolvulus and Convolvulus arvensis, was very weak against Echinochloa crus-galli, was weak, moderately effective against Sinapis arvensis and Solanum nigrum, and showed acceptable efficacy against Portulaca oleracea. Basagran 480 SL was ineffective against Echinochloa crus-galli, had a very weak herbicide against Portulaca oleracea, Solanum nigrum and Convolvulus arvensis, and was moderately effective against the weed Sinapis arvensis. Pulsar 40 SL was ineffective against Convolvulus arvensis, proved to be very weak against Echinochloa crus-galli and Solanum nigrum, had a moderate herbicidal effect against Fallopia convolvulus and was very good - excellent against Sinapis arvensis and Portulaca oleracea. Corum had a weak herbicidal activity against Echinochloa crus-galli, Solanum nigrum and Convolvulus arvensis, moderate activity against Fallopia convolvulus, and excellent against Sinapis arvensis and Portulaca oleracea. In our experiment, Dash HC adjuvant did not significantly affect herbicidal efficacy.

Table 6

Weed control efficiency of the 6 most significant weeds in 2019

\begin{tabular}{|c|c|c|c|c|c|c|c|}
\hline \multirow{2}{*}{ Treatments } & \multirow{2}{*}{ Date } & \multicolumn{6}{|c|}{ Weed control efficiency (\%) } \\
\hline & & SINAR & POROL & ECHCG & SOLNI & POLCO & CONAR \\
\hline \multirow{6}{*}{$\begin{array}{l}3 \text { (Stomp } \\
\text { Super) }\end{array}$} & 17 April & 52 & - & - & - & - & - \\
\hline & 15 May & 81 & 100 & 50 & 73 & 10 & 11 \\
\hline & 22 May & 52 & 94 & 100 & 65 & 10 & 14 \\
\hline & 18 June & 50 & 46 & 100 & 54 & 14 & 20 \\
\hline & 25 June & 30 & 42,5 & 100 & 50 & 23 & 23 \\
\hline & 13 August & - & 2,5 & 100 & 0 & - & 30 \\
\hline \multirow{4}{*}{$\begin{array}{l}4 \text { (Basagran } \\
480 \mathrm{SL} \text { ) }\end{array}$} & 22 May & 87 & 50 & 10 & 51 & 70 & 47 \\
\hline & 18 June & 80 & 30 & 10 & 30 & 40 & 30 \\
\hline & 25 June & 100 & 60 & 15 & 45 & 85 & 60 \\
\hline & 13 August & - & 54 & 15 & 43 & - & 56 \\
\hline \multirow{6}{*}{$\begin{array}{l}\mathbf{5} \text { (Stomp } \\
\text { Super + } \\
\text { Basagran } 480 \\
\text { SL) }\end{array}$} & 17 April & 50 & - & - & - & - & - \\
\hline & 15 May & 80 & 100 & 50 & 70 & 10 & 10 \\
\hline & 22 May & 87 & 50 & 10 & 51 & 70 & 47 \\
\hline & 18 June & 100 & 55 & 12 & 49 & 83 & 59 \\
\hline & 22 June & - & 61 & 16 & 43 & 86 & 60 \\
\hline & 13 August & - & 55 & 16 & 44 & - & 55 \\
\hline
\end{tabular}


Continuation of Table 6

\begin{tabular}{|c|c|c|c|c|c|c|c|}
\hline \multirow{2}{*}{ Treatments } & \multirow{2}{*}{ Date } & \multicolumn{6}{|c|}{ Weed control efficiency (\%) } \\
\hline & & SINAR & POROL & ECHCG & SOLNI & POLCO & CONAR \\
\hline \multirow{4}{*}{6 (Corum) } & 22 May & 100 & 100 & 50 & 60 & 80 & 57 \\
\hline & 18 June & 100 & 100 & 40 & 50 & 90 & 50 \\
\hline & 25 June & 100 & 100 & 60 & 65 & 95 & 60 \\
\hline & 13 August & 100 & 100 & 80 & 70 & - & 65 \\
\hline \multirow{4}{*}{$\begin{array}{l}7 \text { (Pulsar } \\
40 \mathrm{SL} \text { ) }\end{array}$} & 22 May & 100 & 98 & 50 & 60 & 76 & 10 \\
\hline & 18 June & 100 & 98 & 40 & 45 & 70 & 10 \\
\hline & 25 June & 100 & 100 & 48 & 55 & 80 & 10 \\
\hline & 13 August & - & 100 & 86 & 75 & - & 10 \\
\hline \multirow{4}{*}{$\begin{array}{l}8 \text { (Corum } \\
+ \text { Dash HC) }\end{array}$} & 22 May & 100 & 100 & 55 & 60 & 85 & 60 \\
\hline & 18 June & 100 & 100 & 40 & 50 & 90 & 48 \\
\hline & 25 June & 100 & 100 & 65 & 66 & 95 & 65 \\
\hline & 13 August & - & 100 & 75 & 76 & - & 70 \\
\hline
\end{tabular}

The effect of the treatments of 2018 and 2019 on the yield elements of chickpeas can be illustrated graphically in Figure 1 and Figure 2. For both years, the data are from plots of the 'Reale' variety, where the $100 \%$ level is made up of the yield elements of the weed-free plots, and the yield elements of the other treatments are compared to this. Figure 1 shows that the number of shoots per unit area $\left(1 \mathrm{~m}^{2}\right)$ of weedfree plots that did not control weeds was $15 \%$, the number of pods $45 \%$, the number of seeds $58 \%$ and the weight of seeds $49 \%$ less than the weed-free control plots the same crop elements. Weeds were also significantly present in the plots treated only with pre-emergence treatment in the second half of the growing season, so the number of shoots per unit area was 3\%, the number of pods $23 \%$, the number of seeds $34 \%$ and the seed weight $35 \%$ lower, as on weed-free plots. In the case of herbicide treatments, the decrease in yield elements was much smaller: the number of plants per unit area by $1 \%$, the number of shoots by $3-10 \%$, the number of pods by $5-12 \%$, the number of seeds by $13-18 \%$, the seed weight was by $1-5 \%$ less than on mechanically weed-controlled plots.

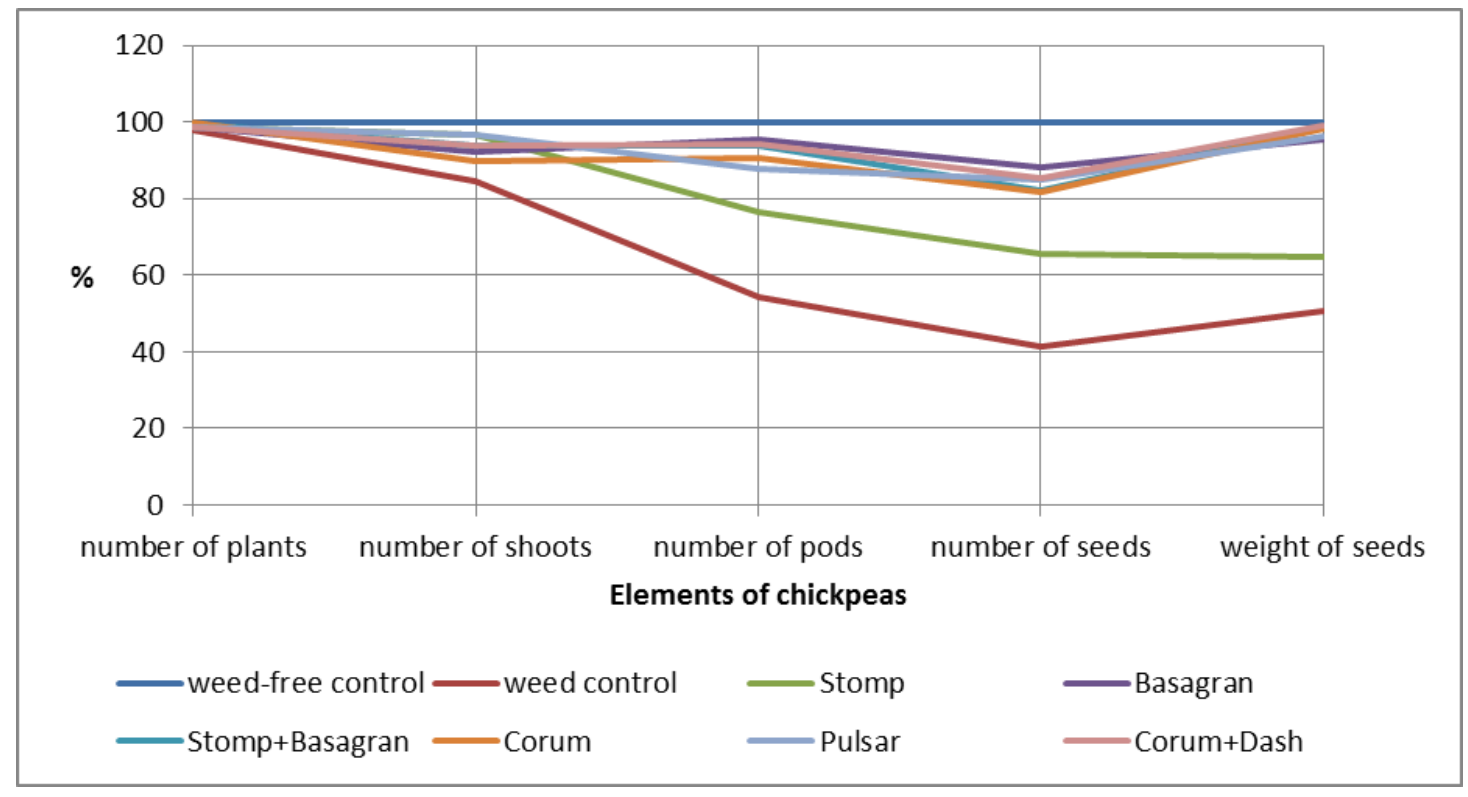

Figure 1. Evaluation of phytotoxicity by cumulative yield analysis for 'Reale' cultivar in 2018 


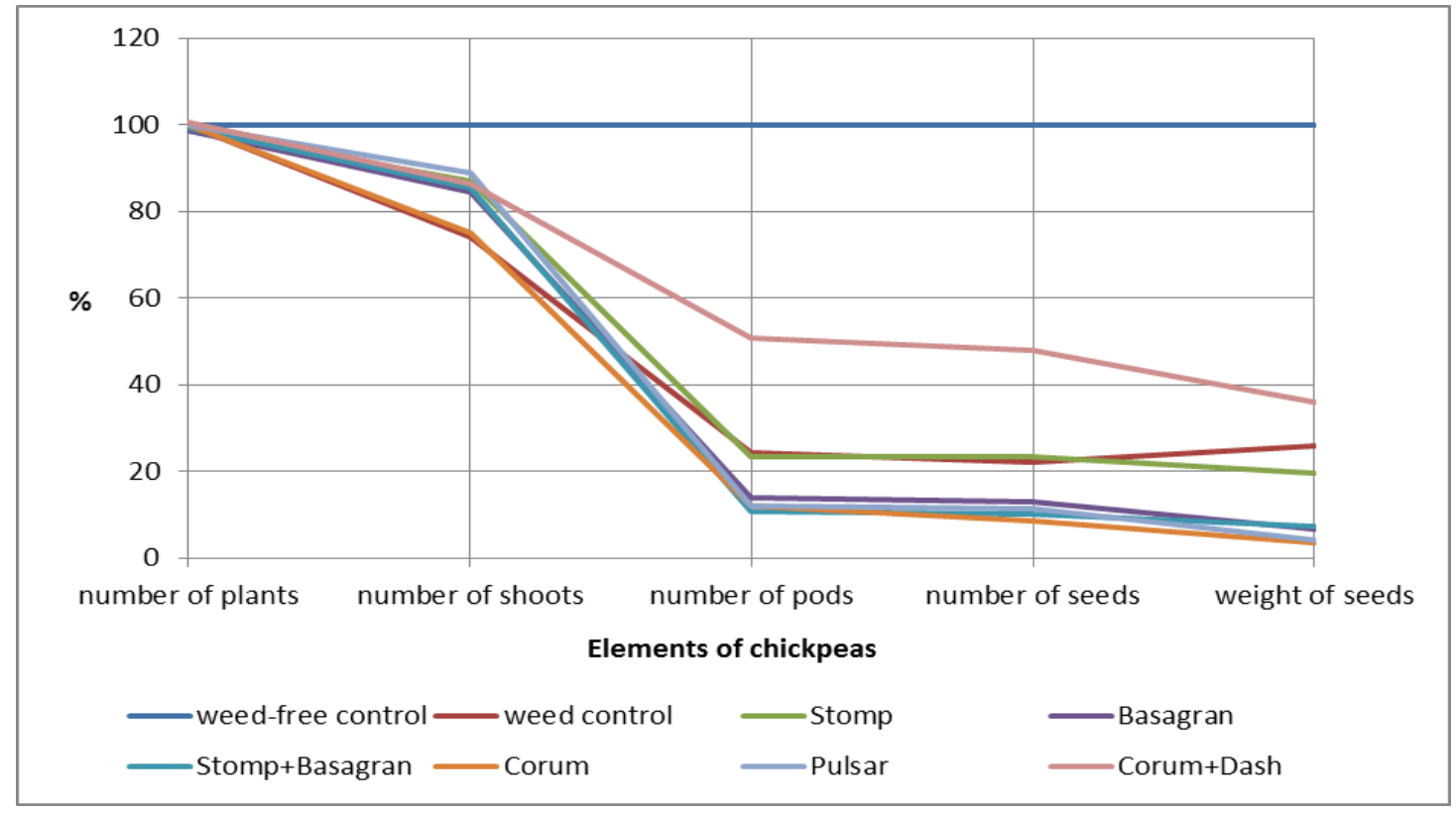

Figure 2. Evaluation of phytotoxicity by cumulative yield analysis for 'Reale' cultivar in 2019

The statistical evaluation of the data can be studied in Table 7. It can be seen from the 2018 data set that the individual treatments did not differ statistically in the values of number of plants and number of shoots per area. On the other hand, in terms of the number of pods per unit area, weed plots show statistically lower values than plots treated with Basagran, Stomp Super + Basagran, Corum, Pulsar, Corum + Dashal, and weed-free plots all the way. By statistically evaluating the number of seeds per square meter, we were able to show a significant difference between weeds and other treatments, as well as between Stomp superes alone and other treatments. In terms of seed weight per unit area, weed plots show statistically lower values than plots treated with Basagran, Stomp Super + Basagran, Corum, Pulsar, Corum + Dashal, and weed-free plots.

Table 7

The effect of weed control technologies on the yield elements of chickpeas per unit area

\begin{tabular}{|c|c|c|c|c|c|c|}
\hline Year & Treatments & $\begin{array}{l}\text { number of } \\
\text { plants } / \mathrm{m}^{2}\end{array}$ & $\begin{array}{l}\text { number of } \\
\text { shoots } / \mathrm{m}^{2}\end{array}$ & $\begin{array}{c}\text { number of } \\
\text { pods } / \mathrm{m}^{2}\end{array}$ & $\begin{array}{c}\text { number of } \\
\text { seeds } / \mathrm{m}^{2}\end{array}$ & $\begin{array}{l}\text { weight of } \\
\text { seeds } / \mathrm{m}^{2} \\
\end{array}$ \\
\hline \multirow{8}{*}{2018} & 1 & $49.00^{a}$ & $32.67^{a}$ & $606.00^{\mathrm{a}}$ & $514.33^{\mathrm{a}}$ & $163,13^{\mathrm{a}}$ \\
\hline & 2 & $49.33^{\mathrm{a}}$ & $37.33^{\mathrm{a}}$ & $856.67 \mathrm{ab}$ & $811.00^{\mathrm{b}}$ & $207,75^{\mathrm{ab}}$ \\
\hline & 3 & $49.33^{a}$ & $35.67^{\mathrm{a}}$ & $1,065.67^{b}$ & $1,089.33^{c}$ & $307,41^{b}$ \\
\hline & 4 & $49.67^{a}$ & $36.27^{a}$ & $1,050.00^{\mathrm{b}}$ & $1,017.67 \mathrm{bc}$ & $316,61^{b}$ \\
\hline & 5 & $50.00^{\mathrm{a}}$ & $34.67^{a}$ & $1,014.33^{b}$ & $1,012.00^{b c}$ & $315,97^{b}$ \\
\hline & 6 & $49.33^{\mathrm{a}}$ & $37.33^{\mathrm{a}}$ & $981.00^{\mathrm{b}}$ & $1,050.00^{b c}$ & $309,65^{b}$ \\
\hline & 7 & $49.33^{a}$ & $36.33^{a}$ & $1,052.67^{b}$ & $1,057.00^{b c}$ & $318,60^{\mathrm{b}}$ \\
\hline & 8 & $50.00^{\mathrm{a}}$ & $38.67^{a}$ & $1,118.00^{\mathrm{b}}$ & $1,238.00^{c}$ & $321,48^{b}$ \\
\hline \multirow{8}{*}{2019} & 1 & $50.00^{\mathrm{a}}$ & $28.67^{a}$ & $246.33^{\mathrm{ab}}$ & $238.33^{\mathrm{ab}}$ & $76,60^{a}$ \\
\hline & 2 & $49.33^{\mathrm{a}}$ & $33.67^{a b}$ & $236.67^{a b}$ & $251.33^{\mathrm{ab}}$ & $58,14^{\mathrm{a}}$ \\
\hline & 3 & $49.67^{a}$ & $32.67 \mathrm{ab}$ & $141.00^{\mathrm{a}}$ & $140.33^{a}$ & $19,98^{\mathrm{a}}$ \\
\hline & 4 & $50.00^{a}$ & $33.00^{\mathrm{ab}}$ & $111.33^{\mathrm{a}}$ & $109.33^{a}$ & $21,36^{a}$ \\
\hline & 5 & $50.00^{a}$ & $29.00^{a}$ & $90.00^{a}$ & $92.33^{a}$ & $10,88^{a}$ \\
\hline & 6 & $50.00^{\mathrm{a}}$ & $34.33^{\mathrm{ab}}$ & $124.00^{\mathrm{a}}$ & $123.33^{a}$ & $12,40^{\mathrm{a}}$ \\
\hline & 7 & $50.33^{\mathrm{a}}$ & $33.33^{\mathrm{ab}}$ & $517.00^{\mathrm{b}}$ & $517.67^{b}$ & $106,20^{\mathrm{a}}$ \\
\hline & 8 & $50.00^{\mathrm{a}}$ & $38.67^{b}$ & $1,016.67^{c}$ & $1,077.00^{c}$ & $295,68^{b}$ \\
\hline
\end{tabular}

Note: Each year, within each column, the values marked with different letters $(a, b, c)$ differ significantly at the $\mathrm{p}<0.05$ significance level. 
The graphical yield analysis shown in Figure 2 shows that there was a much larger difference between the yield elements of the weed-free control treatment and the yield elements of the other treatments in 2019 than in 2018. Compared to the yield elements of the weed-free plots, Corum + Dash HC treatment reduced the number of shoots per unit area by $14 \%$, the number of pods by $49 \%$, the number of seeds by $52 \%$ and the weight of seeds by $64 \%$. The yield elements of the other treatments show even smaller values on the graph: the number of shoots per unit area decreased by $11-26 \%$, the number of pods by $36-$ $89 \%$, the number of seeds by $77-91 \%$, and the seed weight by $74-96 \%$ compared to the plot. This drastic decrease in yield elements is due to the weed conditions of the 2019 vintage in the case of the all-weed control plots and the only preemergent Stomp super treatment, i.e. the significant secondary weeding caused by the late rains. In the case of herbicide treatments, the large decrease in yield elements may be due to the double dose and the treatments carried out in the inappropriate developmental phase (budding). Looking at the statistical evaluation of Table 7 in 2019, it can be stated that the treatments did not differ in the value of the number of plants per unit area, in contrast, the yields of weed-free plants were significantly higher than the yields of all other treatments. Assessing the number of pods and number of seeds per unit area, it can be seen that there was a significant difference between the weed-free control, Corum + Dash HC, and all other treatments. In terms of seed weight per unit area, all treatments resulted in significantly lower values compared to the weed-free control.

The variation in the development of chickpeas by vintage can be seen graphically in Figure 3, where the $100 \%$ level is made up of the yield elements developed in 2018 in the treatment of the 'Reale' variety throughout the weed-free control and compared to the yield elements formed in the same treatment in the 2019 growing season. The figure shows that compared to 2018, in 2019 the number of seedlings and the number of shoots did not differ, but the number of pods per unit area decreased by $9 \%$, the number of seeds by $13 \%$ and the weight of seeds by $8 \%$. Table 8 shows that between 2018 and 2019, there were significant differences in the values of number of pods, number of seeds and seed weight per unit area.

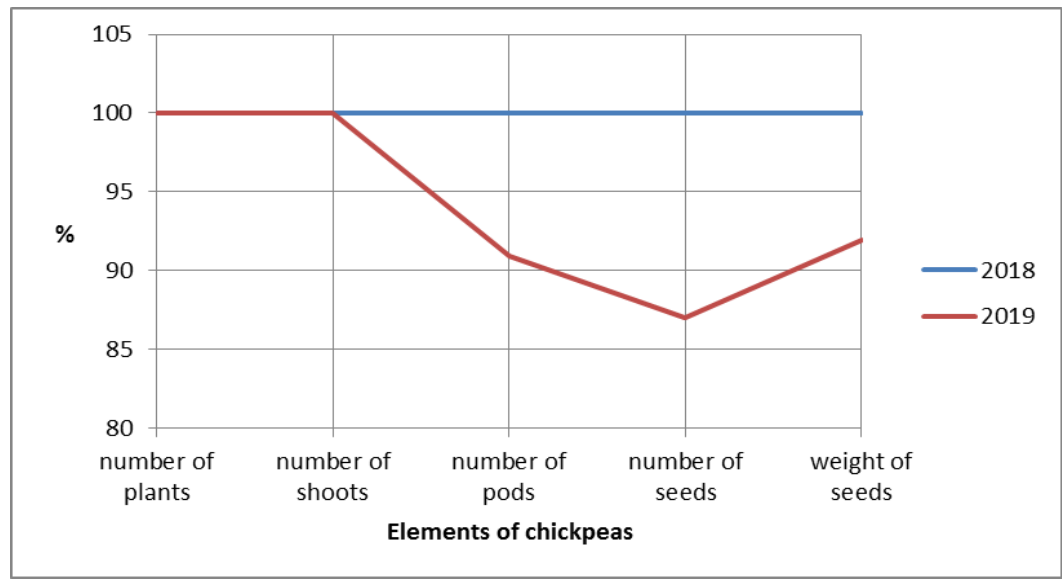

Figure 3. Comparison of examined years with cumulative yield analysis on the basis of weed-free plots of the 'Reale' variety

Table 8

Effect of year on elements of chickpea crop

\begin{tabular}{cccccc}
\hline Year & $\begin{array}{c}\text { number of } \\
\text { plants } / \mathrm{m}^{2}\end{array}$ & $\begin{array}{c}\text { number of } \\
\text { shoots } / \mathrm{m}^{2}\end{array}$ & $\begin{array}{c}\text { number of } \\
\text { pods } / \mathrm{m}^{2}\end{array}$ & $\begin{array}{c}\text { number of } \\
\text { seeds } / \mathrm{m}^{2}\end{array}$ & $\begin{array}{c}\text { weight of } \\
\text { seeds } / \mathrm{m}^{2}\end{array}$ \\
\hline 2018 & $50.00^{\mathrm{a}}$ & $38.67^{\mathrm{a}}$ & $1,118.00^{\mathrm{a}}$ & $1,238.00^{\mathrm{a}}$ & $321.48^{\mathrm{a}}$ \\
2019 & $50.00^{\mathrm{a}}$ & $38.67^{\mathrm{a}}$ & $1,016.67^{\mathrm{b}}$ & $1,077.00^{\mathrm{b}}$ & $295.68^{\mathrm{b}}$ \\
\hline
\end{tabular}

Within the columns, the values denoted by different letters $(a, b)$ differ significantly at the $p<0.05$ significance level.

The developmental characteristics of the cultivars can be observed in Figure 4, where the $100 \%$ level is formed by the yield elements of the 'Bori' variety in the average of all treatments in 2019, and the developmental line of the 'Reale' variety is compared to the average of all treatments in the same year. It can be seen that compared to the desi-type 'Bori' variety, the Kabul-type 'Reale' has $24 \%$ fewer shoots per unit area, 39\% fewer pods per square meter, and 39\% fewer seeds, but its seeds are much larger, making the final phase end product , the seed weight per unit area is $51 \%$ higher. It can be seen from Table 9 that there is no statistically difference between the two cultivars in terms of number of plants and number of 
shoots per unit area, but the number of pods, number of seeds and seed weight per unit area is significantly different for the two cultivars studied.

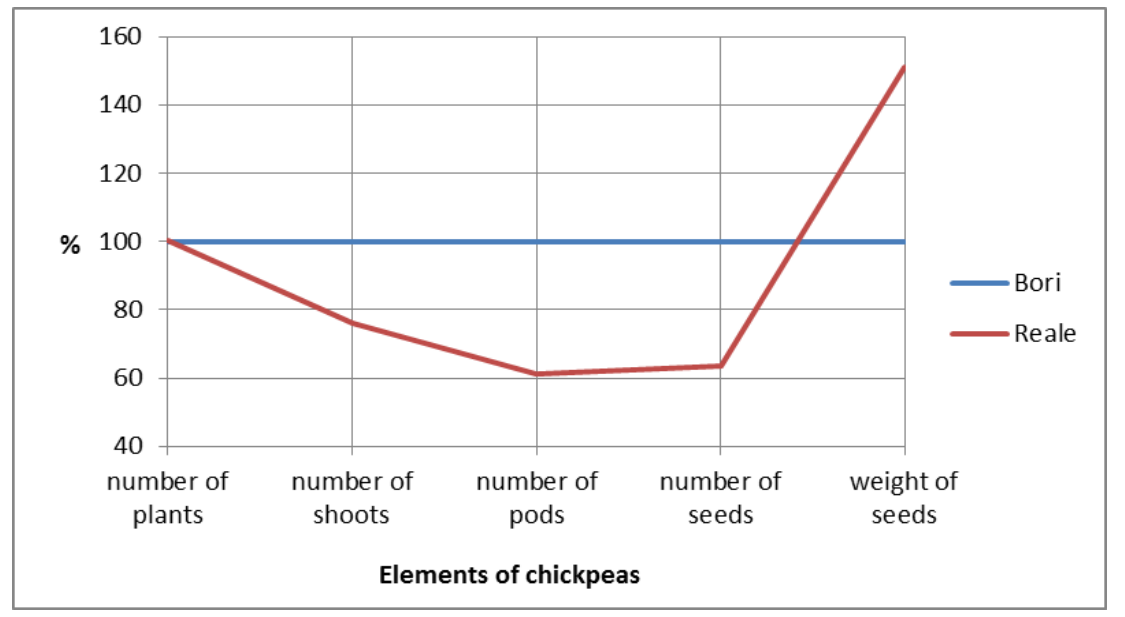

Figure 4. Comparison of studied cultivars with cumulative yield analysis in 2019 in the average of all treatments

Table 9

Varietal effect on the elements of chickpea crop

\begin{tabular}{cccccc}
\hline Varieties & $\begin{array}{c}\text { number of } \\
\text { plants } / \mathrm{m}^{2}\end{array}$ & $\begin{array}{c}\text { number of } \\
\text { shoots } / \mathrm{m}^{2}\end{array}$ & $\begin{array}{c}\text { number of } \\
\text { pods } / \mathrm{m}^{2}\end{array}$ & $\begin{array}{c}\text { number of } \\
\text { seeds } / \mathrm{m}^{2}\end{array}$ & $\begin{array}{c}\text { weight of } \\
\text { seeds } / \mathrm{m}^{2}\end{array}$ \\
\hline Bori & $49.88^{\mathrm{a}}$ & $43.25^{\mathrm{a}}$ & $506.75^{\mathrm{a}}$ & $502.46^{\mathrm{a}}$ & $49.74^{\mathrm{a}}$ \\
Reale & $49.92^{\mathrm{a}}$ & $32.92^{\mathrm{a}}$ & $310.38^{\mathrm{b}}$ & $318.71^{\mathrm{b}}$ & $75.16^{\mathrm{b}}$ \\
\hline
\end{tabular}

Within the columns, the values denoted by different letters $(a, b)$ differ significantly at the $p<0.05$ significance level.

\section{Conclusions}

Our two-year weed survey results show that the later sowing time of chickpeas favored warm-loving weeds. This is in complete agreement with the opinion of Nagy (2017) [13], who found that sowing time determines the predominant weed species in a given area. At the same time, the statement of Kurnik (1970) was not confirmed [15], since in our experiment we proved in the case of 'Reale' cultivar that the later sowing stock in 2018 gave higher yields than the plots with earlier sowing time in 2019. The changing weather caused by climate change makes the site characteristics of the given period much more unpredictable, so the yield is determined much more by the field factors developed during the growing season than by the calendar period.

Although Ratnam et al. (2011), Waqas et al. (2016) and Merga et al. (2019) highlight the maximum herbicidal effect of Stomp in their work, yet in terms of weed cover percentages; the highest value was obtained for the use of Stomp Super after the untreated, all-weed control plot $[5,8,23]$. Although the environmental and agrotechnical conditions were optimal, the reason for the lack of maximum effect is probably due to the short duration of action, and the fact that the weeds appeared masse later in our experiments in warm rainy weather. This is the same as Muhhamad et al. (2011) found that the use of post-emergence herbicides increased yields by a higher percentage compared to pre-emergence herbicides [18].

The weed-suppressing ability of chickpeas is very weak during the initial and flowering period. For this reason, efforts should be made to have a well-closing stock to avoid weed loss [16]. By using the herbicide Stomp Super (in the early stages of development) and Basagran 480 SL (in the budding stage), a medium but continuous herbicidal effect was achieved in the chickpea stock. Even better herbicidal efficacy was achieved with the herbicides containing the active substance imazamox: the persistent effect of Pulsar 40 SL was maintained throughout the growing season, and the weed cover was much lower than in previous treatments. According to Tóth Dobszai (2016) [14], Pulsar 40 SL has only a satisfactory effect against Convolvulus arvensis, which may be the reason why it was present in the highest number of individuals in the sample area, especially by the end of the breeding season. The best herbicidal effect was clearly provided by Corum or its combination with Corum Dash HC. Weeding was almost minimal in both sample 
areas, and their use reduced weed species that were previously difficult to write, such as Fallopia convolvulus or Concvolvulus arvensis. The expected effect of Dash HC was not achieved, no significant difference was observed compared to Corum alone in terms of weed cover.

As there is currently, no herbicide that can be used post-emergence in chickpeas in Hungary, the statement of Nádasdyné (2015) that incorrectly chosen dose or treatment at the wrong time may even cause phytotoxicity must be taken into account for all herbicides to be tested [20]. In our experiments, in the case of post-emergence herbicides applied to fodder peas at the age of 6-8 leaves, Goud et al. (2013) and Taran et al. (2013) [21, 22], we observed morphological changes (chlorosis, leaf twisting, scorching, dehydration). Sváb-types cumulative yield analysis provided an opportunity to measure these changes exactly. In the cumulative yield analysis, we refer to the value of each yield-determining component per unit area, which well characterizes the environmental effects that occurred in the given developmental phases. Crop element changes were also detected for weed control technologies, vintages, and cultivars. Due to the high degree of weeding of our weed-only and pre-emergence-only plots, we were able to demonstrate that Waqas et al. (2016) [8], that is, weed infestation has a significant effect on the growth, development, and development of yield elements in chickpeas. Based on our results, it can be concluded that the active substances bentazone and imazamox not only cause visible phytotoxic symptoms, but also reduce the constituents of the crop. However, the extent of yield loss is highly dependent on the timing and dose of herbicide application.

We have found that the desi and Kabuli-type chickpea cultivars identified by Saxena and Singh (1987) and Gaur et al. (2010) [28, 29], respectively, have different developmental characteristics. The 'Reale' variety of the Kabul type is not so branched, creating fewer shoots, pods and seeds per unit area, but its seeds have a higher thousand-seed weight, so its yield is well ahead of the 'Bori' variety of the desi type. Our results are in line with the findings of Nádasdyné (2015), Taranet et al. (2013), Goud et al. (2013) [20-22], chickpeas are one of the most sensitive crops to herbicides, inappropriate application of herbicides at the right time or dose not only causes phytotoxic symptoms but also individual yields they can also significantly reduce yields.

\section{References}

1. Kismányoky, T. (2005). Hüvelyesek: Növénytermesztéstan 2 [Legumes: Growing plants 2] (pp. 185-191). Budapest: Agriculture publisher. [in Hungarian]

2. Radics, L. (2001). Alternatív növények termesztése I [Growing of alternative crops I.] (pp.17-33). Budapest: Expertise Publishing House. [in Hungarian]

3. FAOSTAT. Retrieved from http://www.fao.org/faostat

4 Yadav, S., Redden, R., Chen, W., \& Sharma, B. (2007). Chickpea breeding and Management. CABI.

5. Merga, B., Alemu, N., \& Yildiz, F. (2019). Integrated weed management in chickpea (Cicer arietinum L.). Cogent Food Agric., 5(1), 1620152. doi: 10.1080/23311932.2019.1620152

6. Radics, L., \& Pusztai, P. (2011). Alternatív növények korszerú termesztése [Modern cultivation of alternative plants] (pp. 34-48). Budapest: Expertise Publishing House. [in Hungarian]

7. Khope, D., Kumar, S., \& Pannu, R. K. (2011). Evaluation of Post-emergence Herbicides in Chickpea (Cicer arietinum). Indian J. Weed Sci., 43(1-2), 92-93.

8. Waqas, M., Khan, I. A., Abu-Rizaiza, A. S., Ihsan, M., \& Daur, I. (2016). Assessment of herbicides and mulches against weeds and yield of chickpea cultivars. Int. J. Biosci., 9(1), 282-290. doi: 10.12692/ijb/9.1.282-290

9. Khan, I. A., Marwat, K. B., Hassan, G., Khan, R., \& Ullah, Z. (2011). Suppresive capability of herbicides and plant extracts against chickpea weeds. J. Anim. Plant Sci., 22, 67-69.

10. Khan, I. A., Waqas, M., Shah, S. M. A., Khan, N., \& Khan, R. (2017). Evaluation of Different Techniques for Economical Control of Weeds Associated to Chickpea. Tunis. J. Plant Prot., 12(Spec. Iss.), 115-122.

11. Khan, I. A., Hussain, Z., Ullah, Z., Khan, R., \& Hassan, G. (2018). Impact of Varous Weed Management Approaches on the Yield of Chickpea Cicer Arietinum L. Crop. Pak. J. Bot., 50(2), 635-638.

12. Antal, J. (2000). Növénytermesztók zsebkönyve [Pocket Book of Plant Growers] (pp.177-179). Budapest: Agriculture Publisher. [in Hungarian]

13. Nagy, M. (2017). Hüvelyesek gyomirtásának lehetőségei és gyakorlati tapasztalatai, Agrofórum extra. $A$ növényvédők és növénytermesztók lapja [Agrofórum extra: Journal of Pesticides and Plant Growers], 70, 90-101. [in Hungarian]

14. Dobszai Tóth, V. (2016). Hüvelyesek. Vegyszeres gyomirtás és termésszabályozás [Legumes. Chemical weed control and crop control] (pp. 268-277). Debrecen: Alföldi printing house. [in Hungarian] 
15. Kurnik, E. (1970). Étkezési és abraktakarmány-hüvelyesek termesztése. [Growing of edible and fodder legumes] (pp. 399-414). Budapest: Academic publisher. [in Hungarian].

16. Nagy, B. (2004). Szántóföldi növények vetőmagtermesztése és kereskedelme. [Field crops seed production and sale] (pp. 363-368). [in Hungarian].

17. Antal, J. (1996). Csicseriborsó: Szántóföldi növénytermesztés. [Chickpeas: Field crop production] (pp. 522-524). Budapest: Agriculture publisher. [in Hungarian]

18. Muhhamad, N., Sattar, A., Ashiq, M., \& Ahmad, I. (2011). Efficacy of pre and Post Emergence Herbicides to Control Weeds in chickpea (Cicer arietinum L.). Pak. J. Weed Sci. Res., 17(1), 17-24.

19. Plew, J. N., Hill, G. D., \& Dastgheib, F. (1994). Weed control in chickpeas (Cicer arietinum). Proceedings agronomy society of New Zealand, 24, 117-124.

20. Nádasdyné Ihárosi, E. (2015). A borsó gyomnövényei és gyomirtása. Agrofórum. A növényvédők és növénytermesztök lapja [Agroforum: Journal of Pesticides and Plant Growers], 2, 26-28. [in Hungarian]

21. Goud, V. V., Murade, N. B., Khakre, M. S., \& Patil, A. N. (2013). Efficacy of Imazethapyr and Quizalofop-ethyl herbicides on growth and yield of chickpea. The Biascan, 8(3), 1015-1018.

22. Taran, B., Holm, F., \& Banniza, S. (2013). Response of chickpea cultivars to pre- and post-emergence herbicide applications. Can. J. Plant Sci., 93(2), 279-286. doi: 10.4141/cjps2012-167

23. Ratnam, M., Rao, A. S., \& Reddy, T. Y. (2011). Integrated Weed Management in Chickpea (Cicer arietinum L.). Indian J. Weed Sci., 43(1-2), 70-72.

24. Soudhia, S. (2012). Dissipation of Pendimethalin in soil and Its Residues in chickpea (Cicer arietinum L.) Under field Conditions. Bulletin of Environmental Contamination and Toxicology, 89(5), 1032-1036.

25. Sváb, J. (1961). Új terméselemzési módszer a növényfajták fejlődésének jellemzésére. MTA Agrártudományok Osztályának Közleményei [Publications of the Department of Agricultural Sciences of the Hungarian Academy of Sciences], 19, 253-261. [in Hungarian]

26. Sváb, J. (1962). Trágyázási és egyéb agrotechnikai kísérletek értékelése kumulatív terméselemzéssel. Agrokémia és talajtan [Agrochemistry and soil science], 11(2), 219-236. [in Hungarian]

27. Sváb, J., \& Szabó, M. (1973). A búzatermés növekedésének vizsgálata terméselemzéssel, 1954-1972 években. Növénytermelés [Crop production], 22(4), 289-300. [in Hungarian]

28. Saxena, M. C., \& Singh, K. B. (1987). The chickpea. Commonwealth Agricultural Bureaux International. UK: Wallingford, Oxon.

29. Gaur, P. M., Tripathi, S., Laxmipathi Gowda, C. L., Ranga Rao, G. V., Sharma, H. C., Pande, S., \& Sharma, M. (2010). Chickpea Seed Production Manual. International Crops research Insitute for the Semi-Arid Tropics, p. 28.

удК 633.31/.37. 632.51

Kristó I.1 ${ }^{*}$, Tar M.1, Vojnich V. J.2, Nagy M. V. ${ }^{1}$ Вплив технологій боротьби з бур'янами на нут (Cicer arietinum L.) і бур'яни. Новітні агротехнологіï. 2019. № 7. URL: http://jna.bio.gov.ua/article/view/204790.

${ }^{1}$ National Agricultural Research and Innovation Centre, Department of Field Crops Research, Lower Harbor Row 9, H-6726 Szeged, Hungary

${ }^{2}$ University of Szeged Faculty of Agriculture, Andrássy Street 15, H-6800, Hódmezővásárhely, Hungary, *e-mail: kristo.istvan@noko.naik.hu

Мета. Встановити вплив технологій боротьби з бур'янами на нут (Cicer arietium L.) в 2018 і 2019 роках на експериментальній ділянці Szeged-Öthalom. Методи. У перший рік досліджень застосовувався механічний контроль бур'янів з обробкою досходовим гербіцидом (19 травня 2018 р.) і гербіцид у фазі 6-8 листків нуту (20 червня 2018 р.). 2019 рік відрізнявся тим, що після обробки досходовим гербіцидом (10 квітня 2019 р.) повторну обробку нуту в фази 6-8 листків (15 травня 2019 роки) повторювали в фазу бутонізації (18 червня 2019 року). Вплив факторів компонентів врожайності розраховували за допомогою однофакторного дисперсійного аналізу з використанням програмного забезпечення SPSS 22, графічне представлення розвитку рослин виконано шляхом аналізу сукупної врожайності Сваба. Результати. Вплив обробок 2018 і 2019 років на елементи врожайності нуту можна графічно проілюструвати на рис. 1 i рис. 2. Для досліджуваних років використані дані сорту «Реал», де 100 \% рівень складається з елементів врожайності на ділянках без бур'янів і елементи врожайності після інших обробок порівнюються з ними. На малюнку 1 показано, що кількість пагонів на одиницю площі (1 м²) на ділянках без бур'янів, що не були контрольними, становило на 15\%, кількість стручків на 45\%, кількість насіння на 58\% і вага насіння на 49\% менше, ніж на контрольних ділянках без бур'янів у тих же елементів культури. Було відзначено також наявність бур'янів у другій половині вегетаційного періоду на ділянках, оброблених тільки перед посівом, тому кількість пагонів на одиницю площі становило на 3\%, кількість стручків на 23\%, кількість насіння на $34 \%$ і маса насіння на $35 \%$ нижче, ніж на ділянках без бур'янів. У разі обробки гербіцидами зниження врожайності було набагато меншим: кількість рослин на одиницю площі на 1\%, кількість пагонів на 3-10\%, кількість стручків на 5-12\%, кількість насіння на 13-18\%, маса насіння на 1-5\% менше, ніж на контрольних ділянках з механічною обробкою. Висновки. Результати наших дворічних досліджень показують, що більш пізні терміни посіву 
нуту сприяли розвитку теплолюбних бур'янів. Це повністю узгоджується з думкою Nagy (2017), який виявив, що час посіву визначає переважаючі види бур'янів в даному районі. У той же час твердження Кurnik (1970) не було підтверджено, оскільки в нашому експерименті на прикладі сорту 'Reale' ми довели, що за умови більш пізнього часу посіву в 2018 році відзначена більш висока врожайність, ніж на ділянках з більш раннім часом посіву в 2019 році. Зміна погоди, викликана зміною клімату, набагато більш впливає на характеристики ділянки в даний період, тому врожайність визначається більшою мірою польовими факторами, які спостерігаються протягом вегетаційного періоду, ніж календарним періодом.

Ключові слова: нут; сорт; врожайність; рівень поживних речовин.

УДК 633.31/.37. 632.51

Kristó, I.1*, Tar, M.1, Vojnich, V. J.2 , \& Nagy, M. V.1 Влияние технологий борьбы с сорняками на нут (Cicer arietinum L.) и сорняки // Новітні агротехнології. 2019. № 7. URL: http://jna.bio.gov.ua/article/view/204790.

${ }^{1}$ National Agricultural Research and Innovation Centre, Department of Field Crops Research, Lower Harbor Row 9 , H-6726 Szeged, Hungary

2University of Szeged Faculty of Agriculture, Andrássy Street 15, H-6800, Hódmezővásárhely, Hungary, *e-mail: kristo.istvan@noko.naik.hu

Цель. Установить влияние технологий борьбы с сорняками на нут (Cicer arietium L.) в 2018 и 2019 годах на экспериментальном участке Szeged-Öthalom. Методы. В первый год исследований применялся механический контроль сорняков с обработкой довсходовым гербицидом (19 мая 2018 г.) и послевсходовым гербицидом в фазе 6-8 листьев нута (20 июня 2018 г.). 2019 год отличался тем, что после обработки довсходовым гербицидом (10 апреля 2019 г.) повторную обработку нута в фазе 6-8 листьев (15 мая 2019 г.) повторяли в фазу бутонизации (18 июня 2019 г.). Влияние факторов компонентов урожайности рассчитывали с помощью однофакторного дисперсионного анализа с использованием программного обеспечения SPSS 22, графическое представление роста и развития растений выполнено путем анализа совокупной урожайности Сваба. Результаты. Влияние обработок 2018 и 2019 годов на элементы урожайности нута можно графически проиллюстрировать на рис. 1 и рис. 2. Для исследуемых лет взяты данные сорта «Реал», где $100 \%$ уровень состоит из элементов урожайности на участках без сорняков и элементы урожайности после других обработок сравниваются с ними. На рисунке 1 показано, что количество побегов на единицу площади $\left(1 \mathrm{~m}^{2}\right)$ на участках без сорняков, которые не были контрольными, составляло на $15 \%$, количество стручков на 45 \%, количество семян на 58 \% и вес семян на 49 \% меньше, чем на контрольных участках без сорняков у тех же элементов культуры. Было отмечено также наличие сорняков во второй половине вегетационного периода на участках, обработанных только перед посевом, поэтому количество побегов на единицу площади составляло на 3 \%, количество стручков на 23 \%, количество семян на 34 \% и масса семян на 35 \% ниже, чем на участках без сорняков. В случае обработки гербицидами снижение урожайности было намного меньшим: количество растений на единицу площади на $1 \%$, количество побегов на 3-10\%, количество стручков на 5-12\%, количество семян на 13-18\%, масса семян на 1-5 \% меньше, чем на контрольных участках с механической обработкой. Выводы. Результаты наших двухлетних исследований показывают, что более поздние сроки посева нута благоприятствовали развитию теплолюбивых сорняков. Это полностью согласуется с мнением Nagy (2017), который обнаружил, что время посева предопределяет преобладающие виды сорняков в данном районе. В то же время утверждение Kurnik (1970) не было подтверждено, поскольку в нашем эксперименте на примере сорта 'Reale' мы доказали, что при условии более позднего время посева в 2018 году отмечена более высокая урожайность, чем на участках с более ранним временем посева в 2019 году. Изменение погоды, вызванное изменением климата, гораздо более влияет на характеристики участка в данный период, поэтому урожайность определяется в большей степени полевыми факторами, которые наблюдаются в течение вегетационного периода, чем календарным периодом.

Ключевые слова: нут; сорт; урожайность; уровень питательных веществ; норма высева.

Надійшла / Received 20.10.2019

Погоджено до друку / Accepted 05.11.2019 